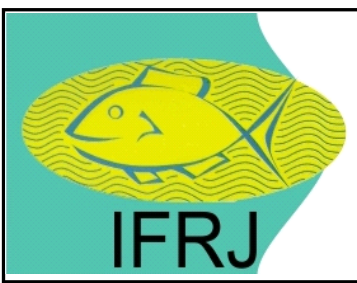

Available online at: http://ejournal-balitbang.kkp.go.id/index.php/ifrj

$$
\text { e-mail:ifrj.puslitbangkan@gmail.com }
$$

INDONESIANFISHERIES RESEARCHJOURNAL

Volume 27 Nomor 2 December 2021

p-ISSN: 0853-8980

e-ISSN: 2502-6569

Accreditation Number RISTEK-BRIN: $85 / M / K P T / 2020$

\title{
TROPHIC INTERACTIONS OF FISH COMMUNITIES IN CIRATA RESERVOIR, WEST JAVA
}

\author{
Agus Arifin Sentosa*1, Astri Suryandari and Amula Nurfiarini \\ ${ }^{1}$ Research Institute for Fish Resource Enhancement, Jalan Cilalawi. No. 1 Jatiluhur, Purwakarta, Jawa Barat, Indonesia 41152 \\ Received; April 20-2020 Received in revised from June 07-2021; Accepted June 24-2021
}

\begin{abstract}
The utilization of food resources by fish communities in Cirata Reservoir depends on the environmental conditions of the reservoir. Eutrophication and the presence of potentially invasive alien fishes could affect the trophic interactions of food utilization by fish communities in the Cirata reservoir. This study aimed to analyze the trophic interactions of the fish communities in Cirata Reservoir, West Java. The samplings were conducted in October 2018, December 2018, and April 2019. The fish samples were collected using experimental gill nets with different mesh sizes. The stomach contents were dissected to study their food habits under a stereoscopic microscope. Data analysis was performed using the index of preponderance, niche breadth, trophic level, and index Schoener. A total of 21 species of fishes in Cirata Reservoir utilized food resources, including phytoplankton, zooplankton, aquatic plants/macrophytes, molluscs, insects (adult and larvae), worms, a body part of fishes and crustaceans, pellets and detritus. The fish communities had a wide range of niches, 0.00-0.32 and trophic levels, 2.00-3.63. The non-native fishes in Cirata Reservoir had the food overlapping potential with native fishes, from low to high categories, especially from the Cichlidae. Trophic interactions of fish communities in Cirata reservoir were still relatively stable, characterized by overlapping food niches in the low to medium categories. The fish stock enhancement effort such as fish introduction or restocking in Cirata Reservoir could still be carried out with a precautionary approach in filling in empty niches and avoiding the potential invasive alien fish species.
\end{abstract}

Keywords: Food habits; trophic guilds; niche breadth; diet overlap; reservoir ecology

\section{INTRODUCTION}

Cirata Reservoir is one of the cascade reservoirs in the Citarum River. It was built in 1987 with the primary function as a power plant and is currently used in fisheries and tourism (Nastiti et al., 2018; Salami et al., 2008). Changes in habitat form from a lotic to a lentic ecosystem have changed the fish communities in Cirata Reservoir, as reported by Kartamihardja (2008) in the Ir. H. Djuanda Reservoir. The environmental dynamics in Cirata Reservoir, such as changes in water quality, pollution, and decreasing carrying capacity, affect fish communities and trophic structures as well as their interactions, especially in terms of utilization of natural food resources.

Fish farming activities in floating net cages in Cirata Reservoir have provided opportunities for the entry of non-native or alien fishes introduced as cultured fish commodities there. The existence of alien fishes in Cirata Reservoir will cause the dynamics of trophic interactions through a process of competition or predation. A study related to the food habits of the fish communities in Cirata Reservoir has been conducted by Tjahjo \& Purnamaningtyas (2008), who mentioned that there are three trophic guilds, namely herbivores, carnivores and predators with a low chance of competition among fish species.

As an ecological system, non-native fishes will affect the structure of fish communities in Cirata Reservoir. Feiner et al. (2013) stated that alien fishes that had become invasive species impact existing established fish communities due to interspeciûc interactions such as competition for food resources. The similarity of food niches among fishes has the potential for food competition (Krebs, 1989). It will affect their trophic interactions in the use of food resources (Smith et al., 2018). The availability of food resources is a determining factor in the stability and survival of fish that will also affect the change in fish food preferences, changes in the area of the food niche and trophic interactions between fish species in the reservoir (Nimet et al., 2015). Therefore, the trophic 
structure of fish communities needs to review again. This study aims to analyze the trophic interactions of fish communities in Cirata Reservoir, West Java.

\section{MATERIALS AND METHODS} Study Site and Data Collection

This research was conducted in Cirata Reservoir, West Java, Indonesia, in October 2018, December
2018 and April 2019 (Figure 1). Sampling was carried out at eight stations, which were considered to represent the Cirata Reservoir condition (Tabel 1). The fish samples were obtained using experimental gill nets made of nylon monofilament with the mesh size of $0.75 ; 1 ; 1.5 ; 2 ; 2.5 ; 3 ; 3.5$, and 4 inches. In addition, fish samples were also obtained from the catches from local fishermen.

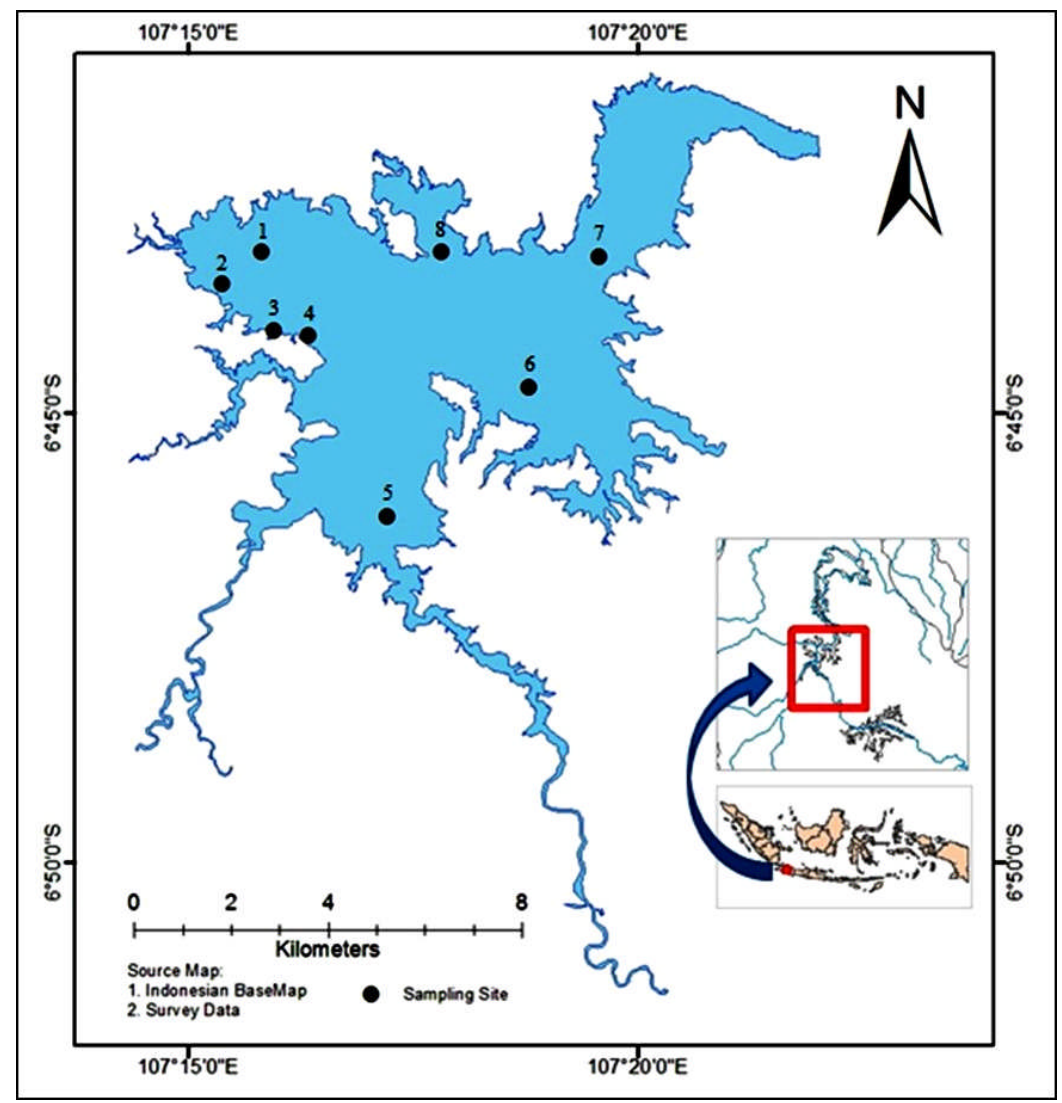

Figure 1. Research location in Cirata Reservoir.

Tabel 1. The description of sampling stations in Cirata Reservoir

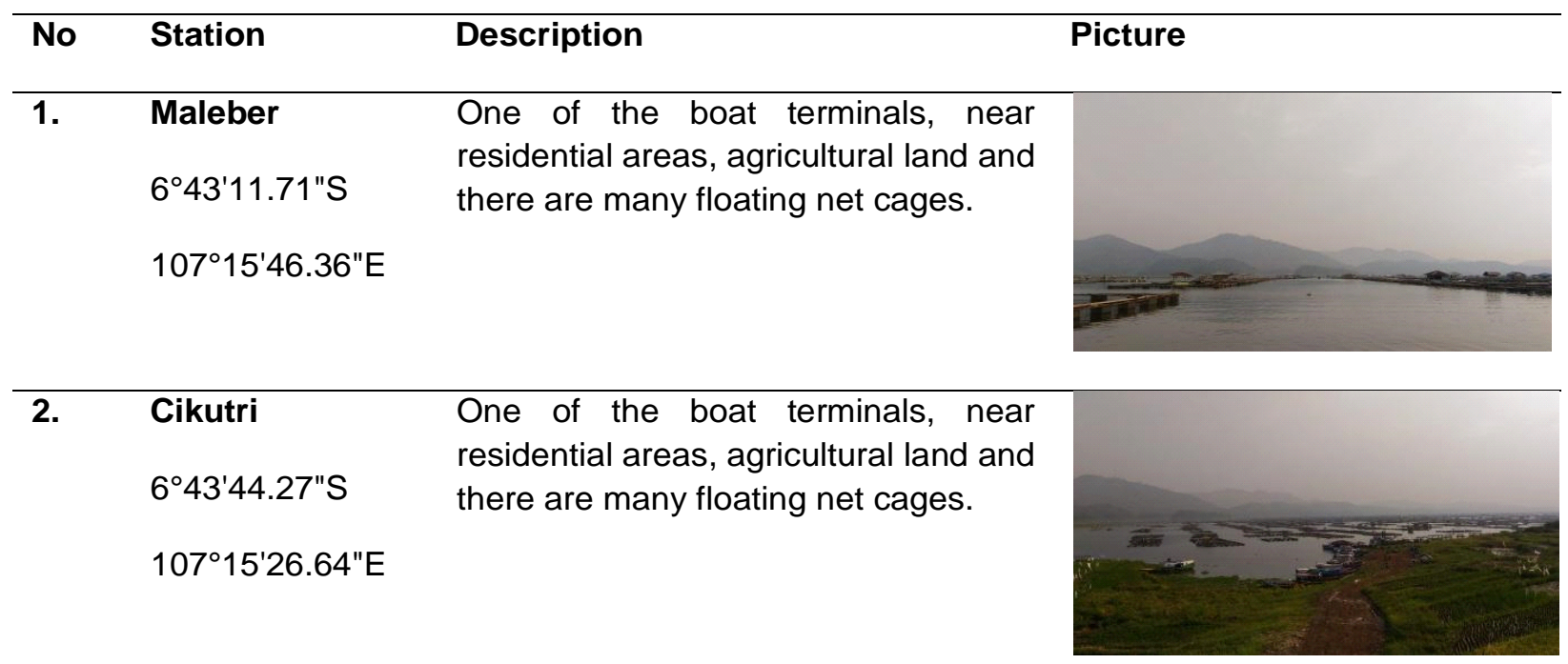




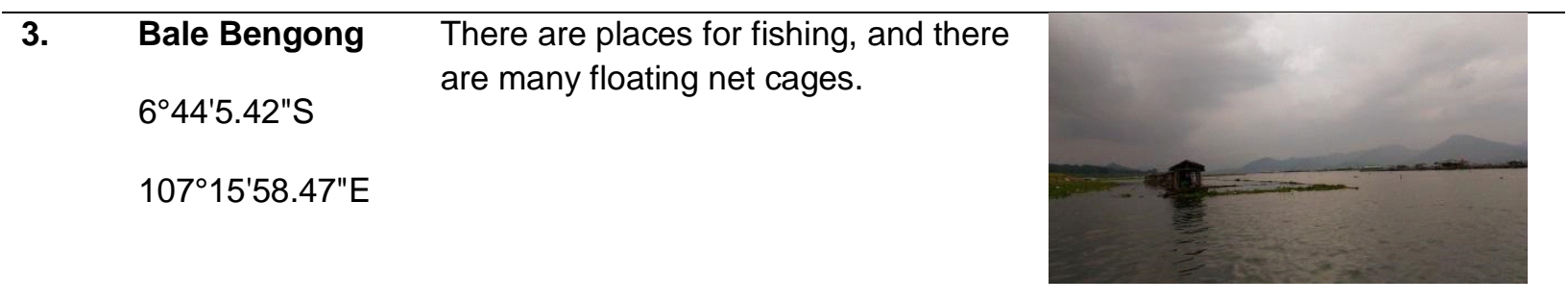

4. Pasir Empul
$\begin{aligned} & \text { One part of the waters that have many } \\ & 6^{\circ} 44^{\prime} 11.08 " S\end{aligned}$
floating net cages.

\begin{tabular}{ll}
\hline Ciranjang & $\begin{array}{l}\text { It is an inlet of the Citarum River, and } \\
\text { there are many floating cages and } \\
\text { water hyacinths that spread. } \\
6^{\circ} 46^{\prime} 8.77 " S\end{array}$ \\
$107^{\circ} 17^{\prime} 12.30 " \mathrm{E}$ &
\end{tabular}

\begin{tabular}{lll}
\hline 6. & Tegal Datar & $\begin{array}{l}\text { One part of the water contained } \\
\text { abundant water hyacinth and floating } \\
\text { net cages. }\end{array}$ \\
$6^{\circ} 44^{\prime} 46.48$ "S &
\end{tabular}

$107^{\circ} 18^{\prime} 48.98 " \mathrm{E}$

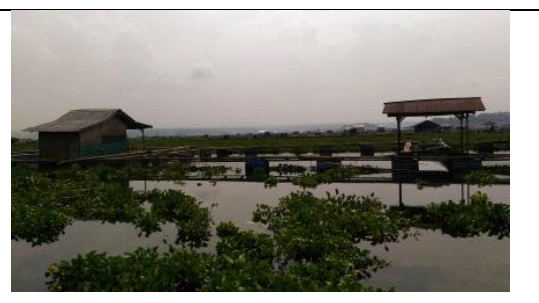

\begin{tabular}{lll}
\hline 7. Near to Dam & $\begin{array}{l}\text { One part of the waters near the Cirata } \\
\text { Reservoir Dam, there is a race rope as } \\
\text { a barrier to large water hyacinth. }\end{array}$ \\
$6^{\circ} 43^{\prime} 18.38^{\prime \prime S}$ &
\end{tabular}

107¹9'35.12"E

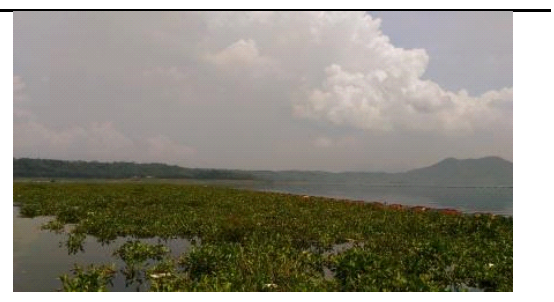

\begin{tabular}{lll}
\hline 8. Jangari & $\begin{array}{l}\text { One part of the water that has many } \\
\text { floating net cages and water } \\
\text { hyacinths, and unfortunately, there }\end{array}$ \\
$6^{\circ} 43^{\prime} 11.61 " \mathrm{~S}$ & $\begin{array}{l}\text { is a lot of y floating garbage. } \\
107^{\circ} 17^{\prime} 49.51^{\prime \prime} \mathrm{E}\end{array}$
\end{tabular}

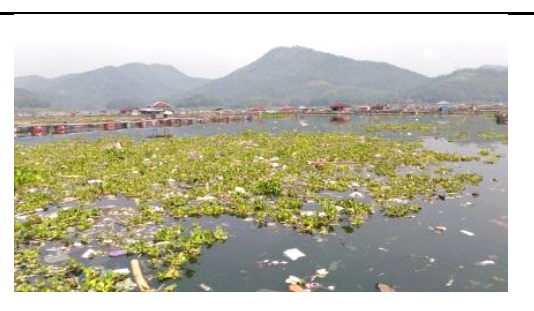

The fish samples were identified according to Kottelat et al. (1993) and the FishBase page (Froese \& Pauly, 2019). Fish samples were then dissected to take the stomach contents, and then it was preserved using a $5 \%$ formalin solution. Analysis of food habits was done at the Biology Laboratory of the Research Center for Fish Resource Enhancement in Jatiluhur, Purwakarta, West Java. Identification of food habits referred to Bellinger \& Sigee, (2010), Robertson et al. (2006), Edmonson (1978), Quigley (1977), and Needham \& Needham (1963). The identification of the remaining food found in the stomach was done under a stereoscopic microscope to the lowest taxonomic level, then grouped by natural food fraction based on TrophLab2K software (Pauly et al., 2000). 


\section{Data Analysis}

The cumulative fish catches were analyzed using the modified index of relative importance (Kolding, 1989; Hedianto \& Sentosa, 2019), with the equation:

$$
I R I=\left(\frac{\left(\% W_{i}+\% N_{i}\right) \times \% F_{i}}{\sum\left(\% W_{i}+\% N_{i}\right) \times \% F_{i}}\right) \times 100
$$

where: $\mid \mathrm{RI}=$ index of relative importance; $\% W i=$ the biomass percentage for the fish $i ; \% \mathrm{Ni}=$ the abundance percentage for the fish $i ; \% F i=$ the occurrence frequency for the fish $i$.

The diet data for food habit were analyzed using the index of preponderance (Natarajan \& Jhingran, 1961), whose formula was:

$$
I i=\frac{\mathrm{V}_{\mathrm{i}} \times \mathrm{O}_{\mathrm{i}}}{\sum_{i=1}^{n}\left(V_{i} x O_{i}\right)} \times 100
$$

where: $l i=$ Index of Preponderance; $V_{i}=$ the volume food percentage for the food type $i ; O_{i}=$ the occurrence food percentage for the food type $i ; n=$ the number of groups in the food $i$. Food grouping: $l i>25=$ basic food, 5 d" lid"25 = secondary food, and $l i<5=$ incidental food (Hedianto et al., 2013).

Determination of the trophic levels of fish was done based on food composition and trophic level of food utilized by fish using TrophLab2K software (Pauly et al., 2000) with the equation was (Christensen \& Pauly, 1992; Pauly et al., 1998):

Troph $=1+\sum_{j=1}^{G} D C_{i j} \times$ Troph $_{j}$

where: Troph $=$ trophic level; $D C_{i j}=$ the fraction of diet $i$ in the consumer $i$; Troph $=$ the trophic level of food $j$; $G=$ the number of groups in the diet $i$.

The niche breadth was calculated to determine whether the fish are specialists or generalists in utilizing available natural food resources. The equation used was the standardized Levins' measure with a value of 0-1 (Krebs, 1989 in Novakowski et al., 2008). The following formula was used:

$$
B_{i}=\frac{1}{(n-1)}\left[\frac{1}{\left(\sum P_{i j}^{2}\right)}-1\right]
$$

where: $B_{i}=$ Levins' measure of niche breadth; $n=$ number of individuals found in or using the resource $i$; $P_{i j}=$ fraction of items in the diet fish $i$ that were of food category $j$. The niche breadth was divided into three classifications, namely, as specialists if $B i<0.4$; intermediate or medium if $0,4 \mathrm{~d}$ "B $i d " 0,6$; and generalists if $\mathbf{B} i>0.6$ (Novakowski et al., 2008).

Trophic interactions of fish communities were based on niche overlaps calculated using the Schoener Index (Collwel \& Futuyma, 1971; Moyle \& Senanayake, 1984; Grossman, 1986) with the equation:

$$
C_{x}=1-\frac{1}{2} \sum\left|P x_{i}-P y_{i}\right|
$$

where: $C_{x}=$ Schoener Index; $P_{x i}, P_{y i}=$ proportion of the diet type $i$ used by the two groups of fish $x$ and $y$.

The niche overlap based on Schoener index values had three classifications: $C_{x}<0.33$ value indicating a low diet overlap, $0.33 \mathrm{~d}$ " $C_{x}$ d" 0.67 indicated moderate diet overlap, and $C_{x}>0.67$ high diet overlap (Moyle \& Senanayake, 1984).

\section{RESULTS AND DISCUSSION Results}

During the study, the fish communities in Cirata Reservoir consisted of 9 families and 23 species, where $56.52 \%$ were non-native fishes. The fish communities caught in Cirata Reservoir during the study were presented in Table 1.

During the study, there were 21 species of fish that were observed for their food habits. The food resources utilized by the fish communities were phytoplankton, zooplankton, aquatic plants/ macrophytes, molluscs, insects (adult and larvae), worms, a body part of fishes and crustaceans, pellets, and detritus. We distinguished pellets from detritus because their shape was still in the form of solids or spheres, while detritus was irregular in shape. There were fish farming activities so that there was an opportunity for fish to eat the released pellets from the floating cage. Especially for pellets, it was only found in C. macropomum, one of the cultivated fish commodities in Cirata Reservoir. Meanwhile, the majority of fish (57.14\%) had macrophytes as their basic food. The percentage of food habits, niche breadth, and trophic level of each fish species were presented in Table 2. 
Table 1. Fish communities caught in Cirata Reservoir during the study

\begin{tabular}{|c|c|c|c|c|}
\hline No & Scientific Names & Common Names & Local Names & \%IRI \\
\hline \multicolumn{5}{|c|}{ Family: Cyprinidae } \\
\hline 1 & Cyclocheilichthys apogon ${ }^{\text {a }}$ & Beardless barb & Corencang & 19.31 \\
\hline 2 & Cyprinus carpio ${ }^{\mathrm{b}}$ & Common carp & Mas & 11.07 \\
\hline 3 & Hampala macrolepidota ${ }^{a}$ & Hampala barb & Hampal & 7.00 \\
\hline 4 & Osteochilus vittatus ${ }^{a}$ & Bonylip barb & Nilem & 4.45 \\
\hline 5 & Rasbora argyrotaenia ${ }^{a}$ & Silver rasbora & Paray & 4.45 \\
\hline 6 & Barbonymus balleroides ${ }^{a}$ & Minnow carp & Lalawak & 3.22 \\
\hline 7 & Labiobarbus leptocheilus $^{\text {a }}$ & Minnow carp & Caren & 1.10 \\
\hline 8 & Mystacoleucus marginatus ${ }^{\text {a }}$ & Minnow carp & Genggehek & 0.35 \\
\hline 9 & Barbodes binotatus ${ }^{b}$ & Spotted barb & Beunteur & 0.06 \\
\hline \multicolumn{5}{|c|}{ Family: Cichlidae } \\
\hline 11 & Oreochromis niloticus ${ }^{\mathrm{b}}$ & Nile tilapia & Nila & 19.45 \\
\hline 12 & Amphilophus citrinellus ${ }^{\mathrm{b}}$ & Midas cichlid & Oskar & 9.18 \\
\hline 13 & Amphilophus labiatus ${ }^{\mathrm{b}}$ & Red devil & Oskar merah & 6.61 \\
\hline 14 & Mayaheros urophthalmus ${ }^{\mathrm{b}}$ & Mexican mojarra & Oskar Hitam & 1.75 \\
\hline 15 & Oreochromis spp. ${ }^{\mathrm{b}}$ & Tilapia & Nila Merah & 0.28 \\
\hline 16 & Cichlasoma trimaculatum ${ }^{\mathrm{b}}$ & Three spot cichlid & Lohan & 0.27 \\
\hline 17 & Parachromis ${ }^{\mathrm{b}}$ & Jaguar guapote & Marinir & 0.23 \\
\hline \multicolumn{5}{|c|}{ Family: Bagridae } \\
\hline \multirow[t]{2}{*}{18} & Mystus nigriceps a & Twospot catfish & Kebogerang & 1.34 \\
\hline & \multicolumn{4}{|l|}{ Family: Clariidae } \\
\hline 19 & Clarias batrachus ${ }^{\text {a }}$ & Philippine catfish & Lele & 0.15 \\
\hline \multicolumn{5}{|c|}{ Family: Serrasalmidae } \\
\hline 20 & Colossoma macropomum ${ }^{\mathrm{b}}$ & Cachama, Pacu & Bawal & 4.79 \\
\hline \multicolumn{5}{|c|}{ Family: Pangasiidae } \\
\hline 21 & Pangasianodon hypophthalmus ${ }^{\text {b }}$ & Striped catfish & Patin & 2.36 \\
\hline \multicolumn{5}{|c|}{ Family: Ambassidae } \\
\hline 22 & Parambassis siamensis ${ }^{b}$ & Glass fish & Kaca & 1.83 \\
\hline \multicolumn{5}{|c|}{ Family: Loricariidae } \\
\hline 23 & Pterygoplichthys pardalis ${ }^{\mathrm{b}}$ & Amazon sailfin catfish & Sapu sapu & 0.6 \\
\hline \multicolumn{5}{|c|}{ Family: Osphronemidae } \\
\hline 24 & Trichopodus pectoralis ${ }^{\mathrm{b}}$ & Snakeskin gourami & Sepat & 0.15 \\
\hline
\end{tabular}


Table 2. Food habits, niche breadth and trophic level of fish communities in the Cirata Reservoir during the study

\begin{tabular}{|c|c|c|c|c|c|c|c|c|c|c|c|c|c|c|}
\hline \multirow{2}{*}{ No. } & \multirow{2}{*}{ Local Names } & \multicolumn{11}{|c|}{ Index of Preponderance (li) } & \multirow{2}{*}{$\begin{array}{l}\text { Trophic } \\
\text { Level }\end{array}$} & \multirow{2}{*}{$\begin{array}{l}\text { Niche } \\
\text { Breadth }\end{array}$} \\
\hline & & A & B & C & D & $\mathbf{E}$ & $\mathbf{F}$ & $\mathbf{G}$ & $\mathbf{H}$ & $\mathbf{I}$ & J & $\mathbf{K}$ & & \\
\hline 1 & Bawal & 8 & 1 & 14 & 0 & 0 & 0 & 0 & 27 & 0 & 17 & 33 & $2.77 \pm 0.46^{\mathrm{omn}}$ & 0.32 \\
\hline 2 & Beunteur & 0 & 0 & 100 & 0 & 0 & 0 & 0 & 0 & 0 & 0 & 0 & $2.00 \pm 0.02^{\text {her }}$ & 0.00 \\
\hline 3 & Caren & 0 & 0 & 37 & 0 & 0 & 63 & 0 & 0 & 0 & 0 & 0 & $2.76 \pm 0.32^{\mathrm{ins}}$ & 0.09 \\
\hline 4 & Corencang & 0 & 0 & 66 & 0 & 0 & 9 & 0 & 0 & 0 & 0 & 25 & $2.11 \pm 0.12^{\text {her }}$ & 0.10 \\
\hline 5 & Genggehek & 0 & 0 & 87 & 0 & 13 & 0 & 0 & 0 & 0 & 0 & 0 & $2.16 \pm 0.14^{\text {her }}$ & 0.03 \\
\hline 6 & Hampal & 0 & 0 & 15 & 14 & 0 & 0 & 0 & 55 & 0 & 0 & 17 & $3.63 \pm 0.62^{\mathrm{car}}$ & 0.17 \\
\hline 7 & Kaca & 3 & 97 & 0 & 0 & 0 & 0 & 0 & 0 & 0 & 0 & 0 & $3.07 \pm 0.28^{\text {her }}$ & 0.01 \\
\hline 8 & Kebogerang & 0 & 0 & 56 & 5 & 5 & 17 & 0 & 0 & 0 & 0 & 17 & $2.35 \pm 0.21^{\text {her }}$ & 0.17 \\
\hline 9 & Lalawak & 1 & 0 & 78 & 20 & 0 & 0 & 0 & 0 & 0 & 0 & 1 & $2.36 \pm 0.21$ her & 0.05 \\
\hline 10 & Lele & 0 & 0 & 85 & 0 & 0 & 15 & 0 & 0 & 0 & 0 & 0 & $2.17 \pm 0.15^{\text {her }}$ & 0.03 \\
\hline 11 & Marinir & 0 & 0 & 30 & 70 & 0 & 0 & 0 & 0 & 0 & 0 & 0 & $3.26 \pm 0.38^{\mathrm{car}}$ & 0.07 \\
\hline 12 & Mas & 4 & 0 & 82 & 10 & 0 & 1 & 3 & 0 & 0 & 0 & 0 & $2.22 \pm 0.16^{\text {her }}$ & 0.05 \\
\hline 13 & Nila & 36 & 16 & 49 & 0 & 0 & 0 & 0 & 0 & 0 & 0 & 0 & $2.18 \pm 0.12^{\text {her }}$ & 0.16 \\
\hline 14 & Nilem & 2 & 0 & 87 & 0 & 0 & 0 & 0 & 0 & 0 & 0 & 11 & $2.00 \pm 0.00^{\text {her }}$ & 0.03 \\
\hline 15 & Oskar Merah & 0 & 0 & 88 & 0 & 0 & 0 & 0 & 0 & 0 & 0 & 11 & $2.00 \pm 0.00^{\text {her }}$ & 0.03 \\
\hline 16 & Oskar & 0 & 0 & 98 & 0 & 0 & 2 & 0 & 0 & 0 & 0 & 0 & $2.02 \pm 0.06^{\text {her }}$ & 0.00 \\
\hline 17 & Paray & 0 & 0 & 10 & 0 & 76 & 14 & 0 & 0 & 0 & 0 & 0 & $3.08 \pm 0.38^{\text {ins }}$ & 0.07 \\
\hline 18 & Patin & 93 & 7 & 0 & 0 & 0 & 0 & 0 & 0 & 0 & 0 & 0 & $2.08 \pm 0.08^{\text {her }}$ & 0.02 \\
\hline 19 & Sapu-Sapu & 50 & 0 & 0 & 0 & 0 & 50 & 0 & 0 & 0 & 0 & 0 & $2.60 \pm 0.28^{\circ \mathrm{mn}}$ & 0.10 \\
\hline 20 & Sepat & 17 & 10 & 0 & 0 & 0 & 50 & 0 & 0 & 0 & 0 & 23 & $2.71 \pm 0.30^{\text {ins }}$ & 0.19 \\
\hline 21 & Oskar Hitam & 0 & 0 & 86 & 0 & 5 & 6 & 0 & 4 & 0 & 0 & 0 & $2.21 \pm 0.20^{\text {her }}$ & 0.03 \\
\hline
\end{tabular}

Remarks: $\mathrm{A}=$ Phytoplankton; $\mathrm{B}=$ Zooplankton; $\mathrm{C}=$ Macrophytes; $\mathrm{D}=$ Mollusc body parts; $\mathrm{E}=$ Insect (adult); F = Insect (larvae); $\mathrm{G}=$ Worm; H = Fish body parts; I = Crustacean body parts; $\mathrm{J}=$ Pellet; $\mathrm{K}=$ Detritus; omn = omnivorous; her = herbivore; ins = insectivorous; $\mathrm{car}=$ carnivorous

The niche breadths of the fish communities ranged from 0.00 to 0.32 , so that almost all fish communities were specialists in utilizing food resources in Cirata Reservoir. Meanwhile, the trophic levels ranged from 2.00 to 3.63 , so that the food web was dominated by herbivorous fish (66.67\%). Some fishes such as Bawal (C. macropomum), Sepat (T. pectoralis), Hampal ( $H$. macrolepidota), Kebogerang (M. nigriceps), and Nila (O. niloticus) tended to be the generalists. These fishes were able to utilize more food sources than other fishes (Figure 2).

Although each fish was commonly specialist, there was a diet overlap opportunity to utilize food resources in Cirata Reservoir. Based on the Schoener index, the non-native fishes in Cirata Reservoir had potential food overlapping with native fishes, from low to high categories, especially from the Cichlidae (Figure 3). 


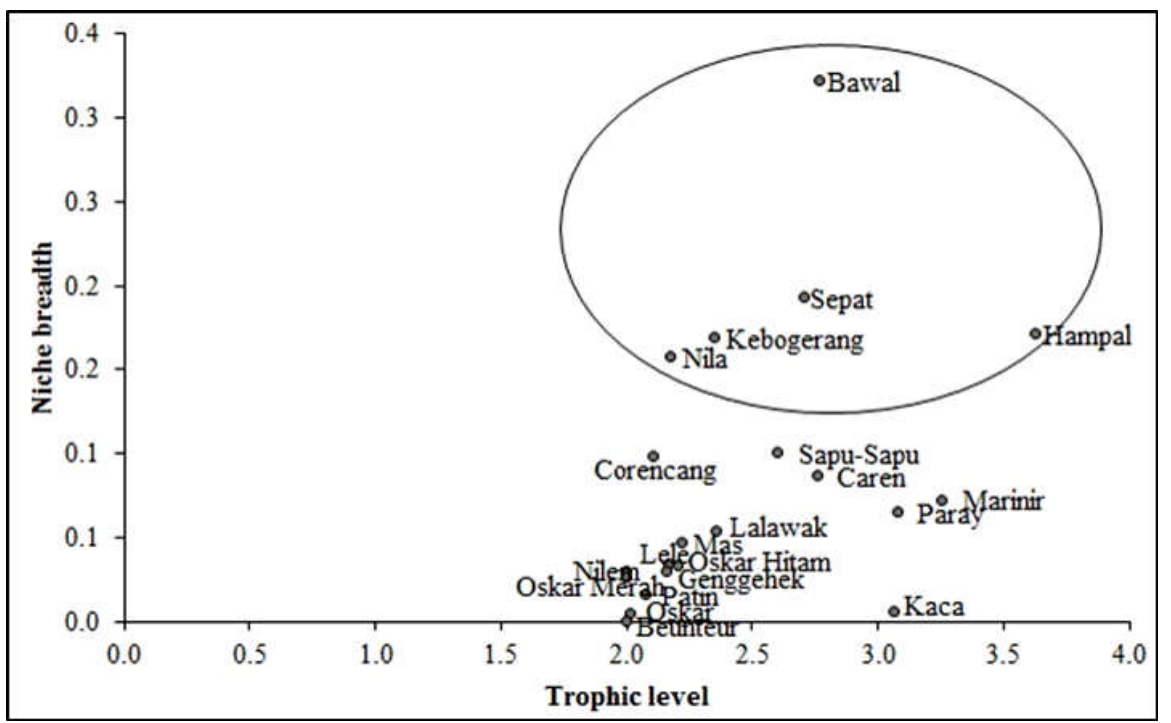

Figure 2. Relationship between trophic level and niche breadth of the fish communities in the Cirata Reservoir.

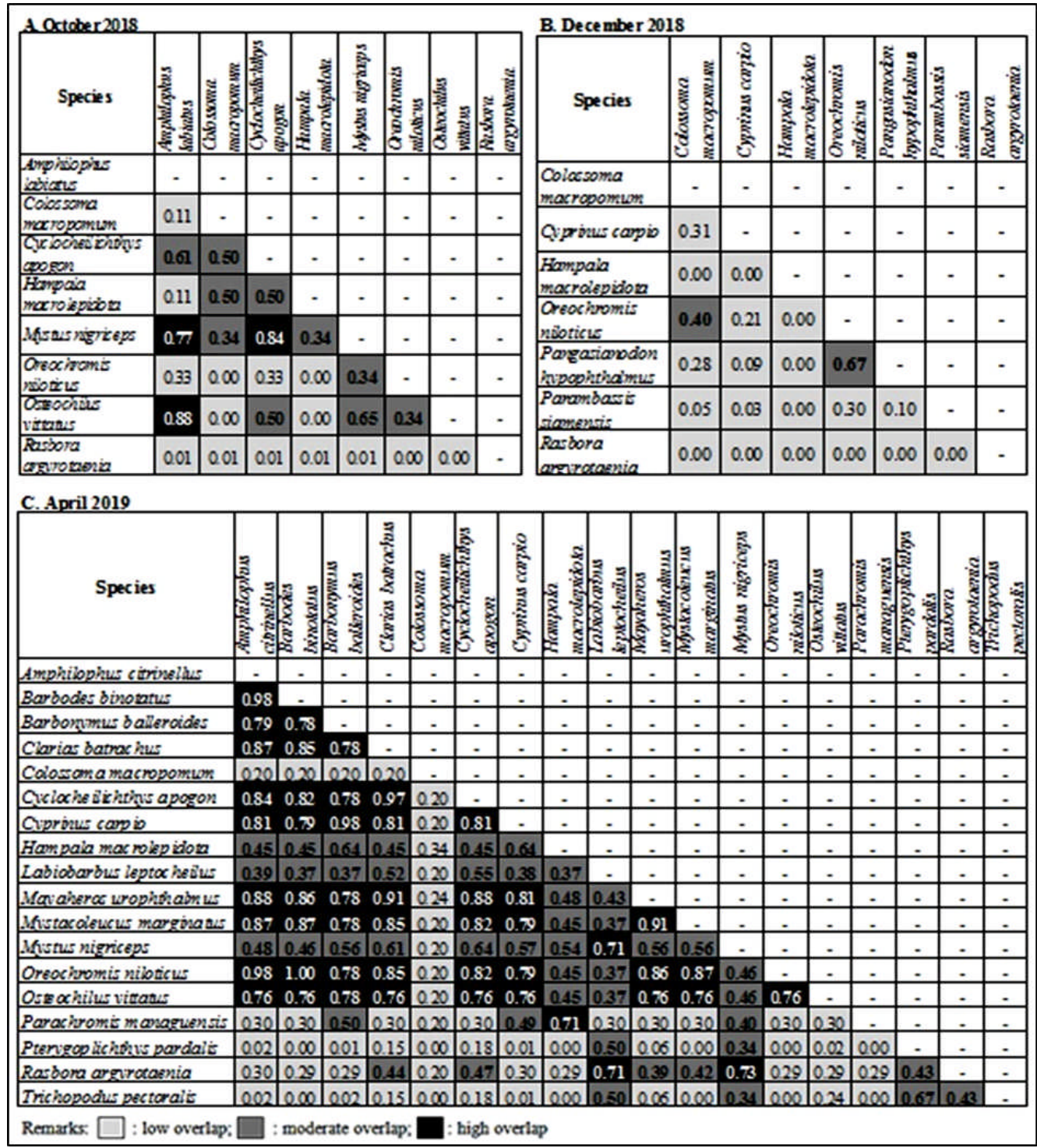

Figure 3. Feeding overlap (Schoener Index) among fish species from fish communities of Cirata Reservoir. 


\section{Discussion}

The existence of fish communities in Cirata Reservoir had existed since the beginning of the reservoir inundation process by the Citarum River flow. During the process, the fish would adapt to the changes in the aquatic environment from lotic to lentic. These environmental changes would undoubtedly impact on the changes in organism interactions and the availability of food resources (Luz-Agostinho et al., 2006; Smith et al., 2018) that were ultimately related to the number of fish species inhabiting the reservoir, which was 23 species with the predominance of non-native fishes $(65.22 \%)$. This species number was higher than the previous report, which was ten species (Tjahjo \& Purnamaningtyas, 2008) and 18 species (Anna et al., 2017). The composition of fish species in Cirata Reservoir was almost similar to fish communities in Ir. H. Djuanda Reservoir (cascade reservoir after Cirata) because it was still in the flow of the Citarum River (Kartamihardja, 2008; Purnamaningtyas \& Tjahjo, 2013).

For 30 years, Cirata Reservoir had been reported to have had a degradation in water quality (Iqbal, 2018). Several studies stated that Cirata reservoir water conditions had reached eutrophic to hypereutrophic levels (Purnamaningtyas \& Tjahjo 2008). Even Damayanti et al. (2010) also reported that Cirata waters contained heavy metals, i.e. $\mathrm{Cd}, \mathrm{Cu}$, and $\mathrm{Zn}$. The concentrations had exceeded the quality standards set by the Republic of Indonesia Government Regulation No. 82 Year 2001. The decrease in water quality in Cirata reservoir would affect the fish communities in that reservoir due to differences in fish adaptation level. The fish communities in Cirata Reservoir might be resistant to poor water quality conditions. Unfortunately, there was no research yet related to that, but fish stocking has always been done in Cirata reservoir. For example, Warsa et al. (2018) suggested mitigating phosphorus pollution from aquaculture by stocking milkfish (Chanos chanos).

The existence of introduced fish is high in Cirata Reservoir, considering the reservoir system is vulnerable to alien fishes entering the reservoir, both intentionally and unintentionally. The reservoir system is generally open, and fish farming activities also have the potential to increase the species and numbers of alien fishes. Tilapia, or Nila as one of the alien fish, had dominated the fish communities in Cirata Reservoir. Nevertheless, this study also reported that the native fish, $C$. apogon, was predominant in Cirata Reservoir. This condition was related to the support from abundant food resources and the existence of eutrophication in that reservoir (Nastiti et al., 2018). The food preference of $C$. apogon consisted of $66 \%$ macrophytes (Table 2). Unfortunately, we could not identify the types of macrophytes in the fish stomach. So we only mentioned macrophytes in general.

The availability of food resources is one important factor that affects the fish communities besides water quality (Quirino et al., 2017). The food resources consumed by fish in Cirata Reservoir include phytoplankton, zooplankton, aquatic plants/ macrophytes, molluscs, insects (adult and larvae), worms, a body part of fishes and crustaceans, pellets and detritus. The presence of pellets in the fish stomach was commonly found in the fish caught around floating net cages. It was suspected that the remains of the pellets came out from the fish culture system to become a food source for fishes outside the cage. Most fish guilds consumed macrophytes as the primary food because of their abundance in the reservoir. Cirata Reservoir was generally allochthonous, with most of the energy and organic material input comes from Saguling Reservoir outlet, agricultural land around the reservoir and tributary rivers that flow into the reservoir (Kholil et al., 2015). The excess of these nutrients can trigger eutrophication. Unfortunately, eutrophication is a symptom of organic pollution in the reservoir, characterized by algae blooms and water hyacinth (Thornton et al., 2013).

The information on the spectrum of food habits of fish communities in this study could provide an updated overview related to the trophic status of each species of fish communities in Cirata Reservoir. The information on trophic structures and resource partitioning of fish communities is essential for understanding ecological relationships among fish species (Woodward \& Hildrew, 2002). The importance of this research in managing the reservoir is as the necessary information for the fish introduction or restocking policies in Cirata reservoir. Therefore, these policies would not harm fish communities, especially related to the invasive alien fish. Luz-Agostinho et al. (2006) stated that the information on the trophic structure of fish communities was fundamental for effective conservation and management of the fish. In general, the fish communities in Cirata Reservoir were dominated by herbivorous fishes. This condition was related to the abundance of macrophytes and phytoplankton as natural foods.

Some alien fishes in Cirata Reservoir, such as $C$. macropomum, A. labiatus, A. citrinellus, and $M$. urophthalmus, were often considered carnivorous fish. However, they were able to adapt to consume 
macrophytes as the primary food. These conditions led alien fishes to live in Cirata Reservoir and could become alien invasive fishes. The macrophytes and plankton could also be complementary diets for fishes at other trophic levels. This phenomenon showed the importance of these food resources for the fish communities, especially in maintaining fish diversity, abundance, and biomass (Vidotto-Magnoni \& Carvalho, 2009). Some species of fish were able to maintain their food habits against environmental changes. Changes in the proportion of food resources can cause changes in fish trophic levels (Agostinho et al., 2008; Smith et al., 2018). Agostinho et al. (1995) stated that the fish diets are based on both the availability and the abundance of food in the environment. The fish might modify their diets according to the characteristics of food resources.

Although the fish communities utilized most of the food resources in Cirata Reservoir, all species relatively exhibited low niche breadth. It indicated that almost all fishes have specialized in the use of available food resources. However, compared to all fish communities, the fishes such as $C$. macropomum, T. pectoralis, $H$. macrolepidota, $M$. nigriceps, and $O$. niloticus were relatively likely to use more food resources than other fish. It was due to their food habits that were relatively varied compared to the others. This result supported the opinion of Novakowski et al. (2008), who stated that high abundance in some food resources would support the presence of fish in their environment and was not related to the limitations of fish morphological characters in the consumption of specific food resources.

The interaction among fish species occurred if the fish species preferred the same type of food as other fish through competition. However, if it was just a similarity in utilizing food, it was called complementary (Tjahjo et al., 2009). Based on the calculation of the Schoener index from sampling at three different times, there were three food overlaps in October 2018, December 2018, and April 2019. The fish that had similarities in food niches in Cirata Reservoir had the opportunity for food overlapping. The overlapping food opportunities in October and December 2018 were relatively lower than in April 2019. In October and December 2018, there are rainy seasons where an allochthonous input of nutrients from outside was higher. It had the consequence that the supply of food resources was relatively abundant, so the opportunity for food overlapping was low. In contrast, April 2019 was the dry season, in which the nutrient input was limited. So, the food availability was low, which would impact on high food overlapping. The number of species in fish communities in April 2019 was also relatively higher, so there was a potential for food overlapping.

The overlapping in food niche utilization is dynamic depending on the availability of food resources. Therefore, different food overlapping opportunities can occur at any time, either daily, monthly or seasonally. It was related to the dynamics of the ecological environment related to the input of food resources and the existence of fish communities (Smith et al., 2018). Although each fish was commonly specialist, there was a diet overlap opportunity to utilize food resources in Cirata Reservoir. Based on the Schoener index, non-native fishes in Cirata Reservoir had potential food overlapping with native fishes, from low to high categories, especially from the Cichlidae. This phenomenon was similar to Feiner et al. (2013), who reported that a non-native fish in North Carolina reservoirs had a high diet overlap with native fishes there.

The average of the Schoener index ranged from 0.12 to 0.47 . This value indicated that the overall opportunities of diet overlapping of fish assemblage in Cirata Reservoir were still low to medium category. It meant that the structure of the niche of the fish communities was still in relatively stable condition. Although the species and fish trophic guilds were relatively different from the report of Tjahjo \& Purnamaningtyas (2008), the fish communities in Cirata Reservoir still indicated low food competition opportunities. This condition was also relatively the same as Vidotto-Magnoni \& Carvalho (2009) reported in Nova Avanhandava Reservoir, Brazil, where the fish communities had a low overlap diet. Based on these results, we recommended that fish stocking or restocking in Cirata Reservoir should be carried out during the rainy season to avoid the potential for high diet overlapping among fishes. Of course, the fish that would be stocked or restocked in Cirata Reservoir must have low-risk biological characteristics to become an invasive species.

\section{CONCLUSIONS}

The trophic interaction of fish communities in Cirata Reservoir was still relatively stable, with the justification of diet overlap in the medium category. It meant that fish stock enhancement efforts such as fish introduction or restocking in Cirata Reservoir could still be carried out with a precautionary approach to filling empty niches and avoiding the potential for invasive alien fish species. 


\section{ACKNOWLEDGEMENTS}

This paper was one output from the research entitled "Research Model for the Development of Culture-Based Fisheries (CBF) in Ir. H. Djuanda Reservoir" in 2018 and "CBF Development Model Research in the Cascade Reservoir of Citarum Watershed" in 2019 at the Research Institute for Fish Resource Enhancement. We would like to thank all who had helped during the field survey. All of the authors are the main contributors to this paper.

\section{REFERENCES}

Agostinho, A. A., Pelicice, F. M., \& Gomes, L. C. (2008). Dams and the fish fauna of the Neotropical region: Impacts and management related to diversity and fisheries. Brazilian Journal of Biology, 68(4 SUPPL.), 1119-1132. https://doi.org/10.1590/ S1519-69842008000500019.

Agostinho, A. A., Vazzoler, A. E. A. M., \& Thomaz, S. M. (1995). The high river Paraná Basin: limnological and ichthyological aspects. In J. G. Tundisi, C. E. M. Bicudo, \& T. Matsumura-Tundisi (Eds.). Limnology in Brazil (pp. 59-103). Sao Paulo: ABC/SBL.

Anna, Z., Suryana, A. A. H., Maulina, I., Rizal, A., \& Hindayani, P. (2017). Biological parameters of fish stock estimation in Cirata Reservoir (West Java, Indonesia): Acomparative analysis of bio-economic models. Biodiversitas, 18(4), 1468-1474. https:// doi.org/10.13057/biodiv/d180424.

Bellinger, E. G., \& Sigee, D. C. (2010). Freshwater Algae, Identification and Use as Bioindicators ( $p$. 271). West Sussex, Chichester: Wiley-Blackwell.

Christensen, V., \& Pauly, D. (1992). The ECOPATH II-a software for balancing steady-state ecosystem models and calculating network characteristics. Ecological Modelling, 61, 169-185. https://doi.org/ 10.1016/0304-3800(92)90016-8.

Collwel, R. K., \& Futuyma, D. J. (1971). On the measurement of niche breadth and overlap. Ecology, 52(4), 567-576. https://doi.org/10.2307/ 1934144.

Damayanti, F. N., Koswara, B., \& Lily, W. (2010). Effect of heavy metal pollution against histology condition of tilapia (Oreochromis niloticus Linn) in floating fish net of Jangari Block of Cirata Dam. Journal of Fisheries and Marine Sciences, 1, 1423.
Edmonson, W. T. (1978). Freshwater Biology. $2^{\text {nd }} E d$ (p. 1248). New York: John Wiley \& Sons, Inc.

Feiner, Z.S., Rice, J.A., \& Aday, D.D. (2013). Trophic niche of invasive white perch and potential interactions with representative reservoir species. Transactions of the American Fisheries Society, 142, 628-641. https://doi.org/10.1080/ 00028487.2013 .763854 .

Froese, R., \& Pauly, D. (Eds.). (2019). FishBase. World Wide Web electronic publication. www.fishbase.org, version (12/2019).

Grossman, G. D. (1986). Food resource partitioning in a rocky intertidal fish assemblage. Journal of Zoology, 1(2), 317-355. https://doi.org/10.1111/ j.1096-3642.1986. tb00642.x.

Hedianto, D.A., \& Sentosa, A.A. (2019). (In Indonesian). Trophic interactions of fish community in Lake Matano, South Sulawesi post-development of invasive alien fish species. J.Lit.Perikan.Ind, 25(2), 117-133. http://dx.doi.org/10.15578/ jppi.25.2.2019.117-133.

Hedianto, D. A., Purnomo, K., \& Warsa, A. (2013). (In Indonesian). Interactions of food resources ut i lization by fish communities in Penjalin Reservoir, Central Java. BAWAL, 5(1), 33-40. http:/ /dx.doi.org/10.15578/ bawal.5.1.2013.33-40.

Iqbal, D. (2018). (In Indonesian). 30 years of Cirata Reservoir, Signed by Water Quality Degradation. https://www.mongabay.co.id/2018/12/07/30-tahunwaduk-cirata-ditandai-penurunan-kualitas-air. Accessed on 2 March 2021.

Kartamihardja, E. S. (2008). (In Indonesian). Change of fish community composition and the influencing important factors during fo rty years of the Djuanda Reservoir impounded. Jurnal Iktiologi Indonesia, 8(2), 67-78. https://doi.org/10.32491/ jii.v8i2.289.

Kholil, Dharoko, T. A., \& Widayati, A. (2015). (In Indonesian). Multidimensional scaling approach to evaluate sustainability of Cirata Reservoir - West Java Province. Jurnal Manusia dan Lingkungan, 22(1), 22-31. https://doi.org/10.22146/jml.18721.

Kolding, J. (1989). The fish resources of Lake Turkana and their environment. Thesis for the Cand. Scient. degree in Fisheries Biology and Final Report of KEN 043 Trial Fishery 1986-1987. University of Bergen. 
Kottelat, M., Whitten, A. J., Kartikasari, S. N., \& Wirjoatmodjo, S. (1993). Freshwater Fishes of Western Indonesia and Sulawesi (p. 293+84). Singapore: Periplus Editions Ltd.

Krebs, C. J. (1989). Ecological methodology (p. 652). New York: Harper and Row Publisher.

Luz-Agostinho, K. D. G., Bini, L. M., Fugi, R., Agostinho, A. A., \& Júlio Jr., H. F. (2006). Food spectrum and trophic structure of the ichthyofauna of Corumbá reservoir, Paraná river Basin, Brazil. Neotropical Ichthyology, 4(1), 61-66. https:// doi.org/10.1590/S1679-62252006000100005.

Moyle, P. B., \& Senanayake, F. R. (1984). Resource partitioning among the fishes of rainforest streams in Sri Lanka. Journal of Zoology, 202(2), 195-223. h t t p s : / / d o i . org/10.1111/j . 1469 7998.1984.tb05951.x.

Nastiti, A. S., Hartati, S. T., \& Nugraha, B. (2018). (In Indonesian). Environmental degradation analysis and its relationship to mass mortality event of cultured fish in the Cirata Reservoir West Java. BAWAL Widya Riset Perikanan Tangkap, 10(2), 99-109. bawal.10.2.2018.83-93.

Natarajan, A. V., \& Jhingran, A. G. (1961). Index of preponderance-a method of grading the food elements in the stomach analysis of fishes. Indian Journal of Fisheries, 8(1), 54-59.

Needham, J. G., \& Needham, P. R. (1963). A Guide to the Study of Freshwater Biology $5^{\text {th }}$ Edition. Revised and Enlarged (p. 180). San Franc isco: Holden Day, Inc.

Nimet, J., Delariva, R.L., Wolff, L.L., \& da Silva, J.J. (2015). Trophic structure of fish fauna along the longitudinal gradient of a first-order rural stream. Acta Limnologica Brasiliensia, 27(4), 381-393. http://dx.doi.org/10.1590/S2179-975X2915.

Novakowski, G. C., Hahn, N. S., \& Fugi, R. (2008). Diet seasonality and food overlap of the fish assemblage in a pantanal pond. Neotropical Ichthyology, 6(4), 567-576. https://doi.org/10.1590/ S1679-62252008000400004.

Pauly, D., Froese, R., Sa-a, P., Palomares, M. L., Christensen, V., \& Rius, J. (2000). TrophLab Manual. Manila: ICLARM.
Pauly, D., Trites, A., Capuli, E., \& Christensen, V. (1998). Diet composition and trophic levels of marine mammals. ICES Journal of Marine Science, 55(3), 467-481. https://doi.org/10.1006/ jmsc.1997.0280.

Purnamaningtyas, S. E., \& Tjahjo, D. W. H. (2013). (In Indonesian). Food habit and niche breadth of some fish species at Djuanda Reservoir, West Java. BAWAL, 5(3), 151-157. http://dx.doi.org/ 10.15578/bawal.5.3.2013.151-157.

Purnamaningtyas, S.E., \& Tjahjo, D.W.H. (2008). (In Indonesian). Observation of water quality to support fishery in Cirata Reservoir. J.Lit.Perikan.Ind, 14(2): 173-180. http://dx.doi.org/10.15578/ jppi.14.2.2008.173-180.

Quigley, M. (1977). Invertebrates of streams and rivers, a key to identification (p. 84). Northampton: Edward Arnold.

Quirino, B. A., Carniatto, N., Guglielmetti, R., \& Fugi, R. (2017). Changes in diet and niche breadth of a small fish species in response to the flood pulse in a Neotropical floodplain lake. Limnologica, 62, 126-131. https://doi.org/10.1016/j.limno.2016.10. 005.

Robertson, T., Sargeant, B., \& Urgellés, R. (2006). Invertebrate Identification Guide (p. 84). Florida: Aquatic Ecology Lab, Florida International University.

Salami, I. R. S., Rahmawati, S., Sutarto, R. I. H., \& Jaya, P. M. (2008). Accumulation of heavy metals in freshwater fish in cage aquaculture at Cirata Reservoir, West Java, Indonesia. Annals of the New York Academy of Sciences, 1140, 290-296. https:/ /doi.org/10.1196/annals.1454.037.

Smith, W. S., Pereira, C. G. F., Espindola, E. L. G., \& Rocha, O. (2018). Trophic structure of the fish community throughout the reservoirs and tributaries of the Middle and Lower Tietê River. Acta Limnologica Brasiliensia, 30(e308), 1-12. https:// doi.org/10.1590/S2179-975X0618.

Thornton, J. A., Harding, W. R., Dent, M., Hart, R. C., Lin, H., Rast, C. L., Rast, W., Ryding, S. O., \& Slawski, T. M. (2013). Eutrophication as a "wicked" problem. Lakes and Reservoirs: Research and Management, 18(4), 298-316. https://doi.org/ $10.1111 /$ Ire.12044. 
Tjahjo, D.W.H., Purnamaningtyas, S. E., \& Suryandari, A. (2009). (In Indonesian). Evaluation of fish speci es role in utilization of food and space resource in Ir. H. Djuanda Reservoir, West Java. J.Lit.Perikan.Ind, 15(4), 267-276. http:// dx.doi.org/10.15578/jppi.15.4.2009.267-276.

Tjahjo, D.W.H., \& Purnamaningtyas, S. E. (2008). (In Indonesian). Study on Food Habit, Niche Breadth, and Species Interaction of Food in Cirata Reservoir, West Java. Jurnal Iktiologi Indonesia, 8(2), 5965. https://doi.org/10.32491/jii.v8i2.288.

Vidotto-Magnoni, A. P., \& Carvalho, E. D. (2009). Aquatic insects as the main food resource of fish the community in a Neotropical reservoir. Neotropical Ichthyology, 7(4), 701-708. https:// doi.org/10.1590/s1679-62252009000400020.
Warsa, A., Hariyadi, J., \& Astuti, L.P. (2018). (In Indonesian). Mitigation of Phosphorus Loading from Aquaculture Activity by Milk Fish (Chanos chanos) Stocking at Cirata, Reservoir, West Java. Jurnal Teknologi Lingkungan, 19(2), 259-266. https://doi.org/10.29122/jtl.v19i2.2669.

Woodward, G. \& Hildrew, A. G. (2002). Food web structure in riverine landscapes. Freshwater Biology, 47(4), 777-798. https://doi.org/10.1046/ j.1365-2427.2002.00908.x. 